M. Klimczuk-Kochańska, A. Klimczuk, Organic Agriculture, [in:] S.N. Romaniuk, M. Thapa, P. Marton (eds.), The Palgrave Encyclopedia of Global Security Studies, Palgrave Macmillan, Cham 2020, pp. 1-7, https://doi.org/10.1007/978-3-319-74336-3 480-1.

\title{
Organic Agriculture
}

Andrzej Klimczuk

SGH Warsaw School of Economics, Warsaw, Poland

Magdalena Klimczuk-Kochańska

University of Warsaw, Warsaw, Poland

Keywords: Alternative agriculture; Biological agriculture; Ecological agriculture; Niche farming; Sustainable agriculture

\section{Definition and Introduction}

Consumers are increasingly aware of the health- and safety-related implications of the food which they can buy in the market. At the same time, households have become more aware of their environmental responsibilities. Regarding the production of food, a crucial and multifunctional role is played by agriculture. The way vegetables, fruits, and other crops are grown and how livestock is raised has an impact on the environment and landscape. Operations performed by farmers, such as water management, can be dangerous for the soil and the whole ecosystem. Consequently, there is a search for natural ways of sustaining the impact of agriculture on the environment. In this context, one of the most popular ideas is organic agriculture.

In the literature on the subject, there are many concepts that some authors consider to be synonymous even as others argue that these terms are not interchangeable. There is, for example, "organic agriculture," “alternative agriculture," “sustainable agriculture," "ecological agriculture," "biological agriculture," "niche farming," "community-supported agriculture," and "integrated pest management." Very often, techniques and products related to organic agriculture are described by marketing experts with the use of abbreviations such as "bio" and "eco." Products with such markings and labels are increasingly popular in stores that often give them separate shelves for their sale. Despite the higher price compared to conventional products, they are increasingly sought by consumers.

The entry examines the various impacts of organic agriculture with a view to these trends.

\section{Features of the Organic Agriculture}

In general, "organic" goods and resources are part of the natural cycle. Organic agriculture is a form of agriculture that relies on nonchemical inputs and ecologically sustainable techniques 
M. Klimczuk-Kochańska, A. Klimczuk, Organic Agriculture, [in:] S.N. Romaniuk, M. Thapa, P. Marton (eds.), The Palgrave Encyclopedia of Global Security Studies, Palgrave Macmillan, Cham 2020, pp. 1-7, https://doi.org/10.1007/978-3-319-74336-3 480-1.

of using the soil, and maintaining control of pests, weeds, and diseases. The core values of organic agriculture are: (1) a holistic view, (2) sustainable cropping methods, (3) respect for nature, that is, no use of chemicals as fertilizers and for pest, disease, and weed control, (4) production of high-quality foodstuffs, and (5) no use of genetically modified organisms (GMOs), neither crops nor animals (Lund and Röcklinsberg 2001; Lairon 2010).

A key feature is the use of specific agritechniques such as crop rotation. Besides that, exceedingly popular is green manure, compost, and biological pest control. The use of ladybirds for a counterattack on aphids in greenhouse horticulture, use of alcohol as a disinfecting agent, or copper sulfates for controlling algae growth is allowed in reference to the "all-natural" principle. Reliance on these methods is also dictated by specific certification rules for organic agricultural producers.

At least three principles of organic agriculture can be identified, such as: (1) the cyclical principle, (2) the precautionary principle, and (3) the nearness principle (Alroe and Kristensen 2002). The first principle is the oldest and most established organic principle, which focuses on the issue of how to interact with nature. It states that organic food systems should emulate and benefit from nature's systems and cycles, fit into them, and help sustain them. This approach combines with the ecological principles and the idea of naturalness, which entails, inter alia, a "nochemicals approach" (Verhoog et al. 2003). The second principle is the precautionary principle, to be applied in decisions on changes in technology and practices. Action should be taken to prevent harm, even if there is no conclusive scientific evidence that this harm will occur. Examples of the implementation of this principle include, among others, the promotion of cleaner, safer technologies, and comprehensive research to detect and reduce risks. The third principle, called the nearness principle, underlines how to learn and communicate about food systems. It states that possibilities for personal experience and close contact between consumers, producers, researchers, and other organic actors should be created and supported. All relevant entities and stakeholders should be involved in the food systems to collectively develop organic agriculture. The most critical issues related to this principle are transparency and cooperation in the production and communication processes related to organic food systems.

Organic agriculture promotes linkages and connections between land, water, plants, and people. It highlights that it is not possible to omit the importance of the balance between nature and human activities and the management of the land. It is thus a philosophical approach in which it is essential to set up a production system that works with nature instead of one that 
M. Klimczuk-Kochańska, A. Klimczuk, Organic Agriculture, [in:] S.N. Romaniuk, M. Thapa, P. Marton (eds.), The Palgrave Encyclopedia of Global Security Studies, Palgrave Macmillan, Cham 2020, pp. 1-7, https://doi.org/10.1007/978-3-319-74336-3 480-1.

dominates nature such as in the case of conventional farming, also known as "industrial agriculture" or "intensive farming. "It is not possible to analyze the concept of organic agriculture only in the context of its impact on the environment. The impact is much broader. The International Federation of Organic Agriculture Movement (IFOAM 2018) promotes principles such as ecology and fairness, implying an "ecological balance" between various species in nature. The idea of balance is essential. Taking it seriously may have major implications. For instance, not all geographical areas should be agricultural in the first place. Taking care of nature and health is only possible in a holistic manner.

\section{Impact on the Environment}

When discussing the impact of agriculture on the natural environment, it should be noted that this is a two-way influence. On the one hand, farming is highly dependent on environmental conditions. Especially in organic production, the farmers face enormous variation in soil, climate, and other environmental factors. On the other hand, conventional agriculture limits the impact of environmental conditions on its production to achieve the goal of making farming more productive. To this end, various techniques are used, such as mechanized tools, new forms of seed-engineering and irrigation, as well as pesticides, herbicides, and fertilizers. All these activities also contribute to the control of environmental conditions.

Conventional farming is informed by a short-term approach, leading to problems such as soil degradation. Meanwhile, organic agriculture is based on the principles that such negative impacts on the environment have to be avoided (Lynch 2009). At a minimum, it is necessary to (1) protect the environment, minimize soil degradation and erosion, decrease pollution, and optimize biological activity and health; (2) maintain soil fertility by optimizing conditions for biological activity within the soil; (3) maintain biological diversity within the impacted ecosystem; (4) recycle materials and resources to the greatest extent possible, and (5) rely on renewable resources in locally produced organic food systems. Thus, one of the goals of organic farming is to improve the quality of the soil.

Soil organic matter is essential for the soil to produce high-quality crops. It is thanks to organic practices such as the application of organic matter (e.g., green or animal manure) that longer and more diverse crop rotations can be supported, reducing soil erosion and fertility decline (Niggli 2015). However, there are also opinions that in some conditions, organic farms cannot be managed correctly and may have a negative environmental impact, including excess erosion. The primary goal of organic agriculture is the conservation of soil and water to enhance 
M. Klimczuk-Kochańska, A. Klimczuk, Organic Agriculture, [in:] S.N. Romaniuk, M. Thapa, P. Marton (eds.), The Palgrave Encyclopedia of Global Security Studies, Palgrave Macmillan, Cham 2020, pp. 1-7, https://doi.org/10.1007/978-3-319-74336-3 480-1.

environmental quality. However, if the soil quality is excellent, there may be problems with pests, weeds, or diseases, especially pest attacks are a primary problem of organic production.

Another critical issue is the efficient use of nutrients. Organic farmers perceive the soil as a living entity. Thus, the soil has particular needs and should be supported by care and nurturement. Higher soil organic matter content increases the soil's water retention capacity and reduces the risk of soil erosion (Muller-Lindenlauf 2009). This situation happens even if contents such as organic matter are added to the soil by applying composts, using organic mulches, or by growing cover crops as part of a crop rotation program. If the soil suffers from a nutrient imbalance or insufficient quantity of nutrient, the quality may be improved by applying selected natural materials such as lime, rock phosphate, or sulfur. All these components impact on soil quality, and, from a production standpoint, the heart of organic farming is considered to be the healthy soil.

Another crucial aim is avoiding and decreasing the probability of the loss of biological diversity through the replacement of natural landscapes with extensive monocultures (e.g., the practice of growing the same crop, at the same location, year after year).

A review of studies showed that organic management is related to a higher soil carbon content and lower emission of carbon dioxide, as compared to conventional management practices (Muller-Lindenlauf 2009). In organic agriculture, biomass burning - a significant contributor to carbon dioxide emissions - is restricted. High carbon sequestration potential is also reported in grassland soils, but organic grassland farming can help to optimize carbon sequestration (Rice and Owensby 2001). For example, by introducing grass and clover leys into the crop rotations as a feedstuff for ruminants, diversifying the crop sequences, as well as by reducing plow depth, soil organic matter can be augmented, thus contributing to carbon sequestration (Niggli 2010).

There exist critical views on organic production. For example, some argue that organic agriculture is an environmentally unsustainable and ineffective approach to farming that does not allow humankind to respond to global challenges such as population growth. It does, however, allow humankind to respond to the challenge of climate change, which poses a fundamental challenge to maintaining stable food production, and it does so by aiding the soil in carbon sequestration (Muller-Lindenlauf 2009).

Further, organic farming is overall less polluting than conventional farming. Unfortunately, however, this statement is only valid if the effects are measured per unit of land. Because lower average yield is obtained by organic agriculture, it is challenging to show irrefutable evidence 
M. Klimczuk-Kochańska, A. Klimczuk, Organic Agriculture, [in:] S.N. Romaniuk, M. Thapa, P. Marton (eds.), The Palgrave Encyclopedia of Global Security Studies, Palgrave Macmillan, Cham 2020, pp. 1-7, https://doi.org/10.1007/978-3-319-74336-3 480-1.

that such agriculture is more environmentally friendly than conventional farming - per unit of output. The bans on synthetic fertilizers, pesticides, and GMOs in organic farming make plant nutrition and pest control difficult and often less effective.

\section{Impact on Society}

Although many people associate organic agriculture primarily with fruits and vegetables, organic agricultural practices are applied effectively to diverse types of crops and animals. Those raising organic livestock need to provide animals with organic feed and access to pasture.

Organic agriculture and its products became especially popular in the 1990s. By linking local geographies to global economies with reference to the phrase "think globally, act locally," organic food moved from its associations with a hippy counterculture to "yuppie chow" (Guthman 2003). At the beginning of the twenty-first century, Millennials (Generation Y) particularly appreciate this approach to agriculture. The contemporary generational demographic cohort perceives organic food production as a public health issue due to fears over a slow degradation of human bodies due to decades of eating food contaminated with dangerous pesticides (e.g., Carson 1962).

The health of individuals and communities cannot be separated from the health of ecosystems. Healthy soils generate healthy crops that foster the health of animals and people. Therefore, for consumers, healthy soil means healthy food, and this may lead to healthy people. Immunity, resilience, and regeneration are essential characteristics of healthy and organic systems. In recent years, several food scandals, for instance, connected to Salmonella outbreaks resulted in changes of attitudes and behaviors on the part of many consumers who feel that the institutions and actors which ought to safeguard the food system are not acting accordingly (Kjarnes et al. 2007). On the other hand, critics underline that organic production of food may itself pose health risks due to the probability of occurrence of foodborne diseases connected to biological contaminants (e.g., Escherichia coli), noroviruses, Campylobacter bacteria, or toxic botanical pesticides.

Organic agriculture is also sometimes presented as a solution to the challenge of feeding the world and ending global hunger in many regions. These phenomena are particularly relevant in the context of population growth. Organic farming is an essential issue in the growth of less developed regions. Despite many advantages, itis noticed that the land-use efficiency of organic farming is quite low compared to conventional farming because organic crop yields are lower than conventional yields on average. Moreover, some organic crop rotations typically include 
M. Klimczuk-Kochańska, A. Klimczuk, Organic Agriculture, [in:] S.N. Romaniuk, M. Thapa, P. Marton (eds.), The Palgrave Encyclopedia of Global Security Studies, Palgrave Macmillan, Cham 2020, pp. 1-7, https://doi.org/10.1007/978-3-319-74336-3 480-1.

crops that are not suitable for human consumption. Also, organic animal husbandry is characterized by longer production cycles and lower animal growth rates, meaning that more significant quantities of fodder and more land for fodder production are needed per unit of organic meat (Treu et al. 2017). Currently observed yield gaps between organic and conventional methods may further increase if a higher number of farmers will switch to organic practices. This is especially relevant in developing countries of the Global South. It is possible to observe that smallholder farmers tend to have low levels of education and limited access to agricultural training. Productivity also depends on many factors, including the farmer's background, the farm's resourcefulness, and local and national support mechanisms set up in more or less formal public policies such as agricultural policy and economic policy (Kristiansen et al. 2006).

\section{Impact on the Economy}

Based on the specific processes of production together with particular distribution and consumption mechanisms, the market of organic food products appeals to "green consumers," that is, consumers concerned with the environment. This growing market is driven by consumers' desire for healthy food along with environmental protection and sustainable development. From a broader perspective, organic food products are part of a "green market" that includes organic products as well as related services and activities that are not only related to farming (such as resource and energy reuse, repairing, refurbishing, retrofitting, remanufacturing, recycling, upcycling, and reselling). Thus, the green market has a lot in common with concepts such as the "informal (or grey) economy," the "permaculture economy," and the "circular economy" (Klimczuk and Klimczuk-Kochańska 2018b).

Consumer interest in organic products may translate into their "conventionalization" (Truninger 2008). Organic food reflects the growth of organic agriculture on a worldwide scale, and it makes globalization increasingly essential for producers, in what is often described as the "organic paradox" (Noe 2006). On the one hand, the preservation of the organic agriculture movement's original principles is associated with localized and re-embedded food systems, while on the other hand, there is a need for the globalization of activities.

There are efforts to manage large-scale organic production with the help of science. Historically speaking, organic farmers have received little support from established research universities (Klimczuk and Klimczuk-Kochańska 2018a). There is also no commonly recognized set of tools and technologies for converting conventional farming into organic farming. It is problematic because to produce something according to the organic agriculture 
M. Klimczuk-Kochańska, A. Klimczuk, Organic Agriculture, [in:] S.N. Romaniuk, M. Thapa, P. Marton (eds.), The Palgrave Encyclopedia of Global Security Studies, Palgrave Macmillan, Cham 2020, pp. 1-7, https://doi.org/10.1007/978-3-319-74336-3 480-1.

principles there is an increasing need to extend the area available for farming production. The existing research supports the idea of using biotechnology, such as genetic modification of plants, to create crops that can resist inconvenient environmental impacts. Studies also support agricultural techniques with the use of expensive synthetic chemicals.

The phenomenon of the growing interest of enterprises from the mainstream food market in the growth of large-scale organic farms means increased distribution to mass-market and natural-food chains. This result is partly related to the profound influence of the idea of corporate social responsibility (CSR). The CSR movement is happy to embrace the "organic" label as part of the implementation of an ethics of care for both humans and nonhumans (Visser 2011). Unfortunately, large-scale organic growers still plant single crops (monoculture crops, such as wheat, soybeans, and corn), rather than fostering biodiversity and crop rotation. They also rely on underpaid seasonal labor (precarious work). These practices have led to questions as to whether large-scale and corporate-owned organic agriculture farms are truly organic in the broad ecological sense.

Further, a motive for farmers to move from conventional to organic production is often a financial incentive, to compensate for the loss of the income from reduced production and added costs related to the implementation of organic farming. Growing demand for organically produced food in the developed countries of the Global North is related to the potential of opening access to premium prices and, hence, higher income (Willer et al. 2009). In industrialized countries, most consumers are sufficiently wealthy, so higher food prices would not jeopardize their food security. However, in developing countries, the situation is different. Many poor households spend over $50 \%$ of their income on food. In such circumstances, food price increases are associated with higher levels of food insecurity and undernutrition, especially in urban areas (Ecker and Qaim 2011). For farming households, higher agricultural prices are welcome as such, but when higher prices are the result of lower yields, they do not necessarily lead to higher incomes.

Additionally, the premium price of food at the retail level is not necessarily reflected in the incomes that farmers receive for their organic production of certified organic products because various entities along the value chain (e.g., food-manufacturing facilities, low-temperature distribution facilities, department stores, and restaurants) also capture a share of the profits (Minten et al. 2018). These significant issues lead to the dynamic growth of the idea and movement of "fair trade," where most organic standards include specific certification and labeling requirements related to social issues, such as the prevention of child labor and the promotion of 
M. Klimczuk-Kochańska, A. Klimczuk, Organic Agriculture, [in:] S.N. Romaniuk, M. Thapa, P. Marton (eds.), The Palgrave Encyclopedia of Global Security Studies, Palgrave Macmillan, Cham 2020, pp. 1-7, https://doi.org/10.1007/978-3-319-74336-3 480-1.

gender equality (Meemken and Qaim 2018; Seufert and Ramankutty 2017). On the one hand, the combined organic and fair trade certification has positive social effects such as poverty reduction and may also be analyzed in the context of the development of "social economy" and "solidarity economy," that is, entities combining production with achieving economic and social goals and solidarity-building (Gitter et al. 2012; Klimczuk and Klimczuk-Kochańska 2015). On the other hand, meeting various certification requirements is often associated with certain investment costs (e.g., new equipment) that farmers have to bear individually (Kleemann et al. 2014). Organic farmers usually undergo a rigorous on-farm certification process before they can label their products as organic. This process, established to protect the consumer, certifies merely the production process, but the organic label itself does not guarantee the safety or chemical composition of the labeled goods. Moreover, the organic labels do not make claims about the quality or nutritional composition of the crop being sold even if the original idea was to support organic farming and limit fraud.

\section{Conclusion}

Although the label "organic" is a recent phenomenon, the concept is deeply rooted in traditional agricultural practices and ideas that were used for thousands of years.

Many consumers prefer modern organic agriculture because of its systemic approach that ties food production to ecology, connecting land, people, plants, and animals to a common goal, that is, a vital, healthy environment for all. In general, the principles that are essential for organic agriculture have a good impact on the environment. Efficient management of soil fertility, crops, livestock, farms, landscape, and the efficient use of nutrients help to reverse the negative consequences of agriculture's impact on nature.

Organic products are not treated with toxic insecticides, herbicides, fungicides, and fertilizers that can linger on the food. Thus, eating organic foods helps alleviate people's concerns over potential unintended consequences of chemical and biochemical compounds for personal and ecological health. At the same time, however, one must also bear in mind the fact that it is not possible to generalize that organic products are safer, more nutritious, and healthier than those coming from conventional farming. By applying organic agriculture principles, it is not possible to obtain the same results from crops in various locations (e.g., in organic winemaking).

The problem of the commercialization of organic food on a large scale is now a critical one. Organic agricultural techniques, the commercial market for organic products, the growing 
M. Klimczuk-Kochańska, A. Klimczuk, Organic Agriculture, [in:] S.N. Romaniuk, M. Thapa, P. Marton (eds.), The Palgrave Encyclopedia of Global Security Studies, Palgrave Macmillan, Cham 2020, pp. 1-7, https://doi.org/10.1007/978-3-319-74336-3 480-1.

number of organic food consumers, and organic certification by governments all arose from concern over conventional farming practices and the modern global food system, but pose challenges as well, connected to the implications and questionable feasibility of the upscaling of truly organic agriculture.

\section{References}

Alroe, H. F., \& Kristensen, E. S. (2002). Towards a systemic research methodology in agriculture: Rethinking the role of values in science. Agriculture and Human Values, 19(1), 3-23.

Carson, R. (1962). Silent spring. New York: Houghton Mifflin.

Ecker, O., \& Qaim, M. (2011). Analyzing nutritional impacts of policies: An empirical study for Malawi. World Development, 39(3), 412-428.

Gitter, S. R., Weber, J. G., Barham, B. L., Callenes, M., \& Valentine, J. L. (2012). Fair tradeorganic coffee cooperatives, migration, and secondary schooling in southern Mexico. Journal of Development Studies, 48(3), 445-463.

Guthman, J. (2003). Fast food/organic food: Reflexive tastes and the making of 'yuppie chow.' Social \& Cultural Geography, 4(1), 45-58.

International Federation of Organic Agriculture Movements (IFOAM). (2018). The principles of organic agriculture. Retrieved from https://www.ifoam.bio/en/organiclandmarks/principles-organic-agriculture

Kjurnes, U., Harvey, M., \& Warde, A. (2007). Trust in food: A comparative and institutional analysis. Basingstoke: Palgrave Macmillan.

Kleemann, L., Abdulai, A., \& Buss, M. (2014). Certification and access to export markets: Adoption and return on investment of organic-certified pineapple farming in Ghana. World Development, 64, 79-92.

Klimczuk, A., \& Klimczuk-Kochańska, M. (2015). Social and solidarity economy. In M. Odekon (Ed.), The SAGE encyclopedia of world poverty (2nd ed., pp. 1413-1416). Los Angeles: SAGE Publications.

Klimczuk, A., \& Klimczuk-Kochańska, M. (2018a). Innovation in food and agriculture. In D. M. Kaplan (Ed.), Encyclopedia of food and agricultural ethics (2nd ed., pp. 1-7).

Dordrecht: Springer Netherlands. https://doi.org/10.1007/978-94-007-6167-4_628-1.

Klimczuk, A., \& Klimczuk-Kochańska, M. (2018b). New economy, food, and agriculture. In D. M. Kaplan (Ed.), Encyclopedia of food and agricultural ethics (2nd ed., pp. 1-7). 
M. Klimczuk-Kochańska, A. Klimczuk, Organic Agriculture, [in:] S.N. Romaniuk, M. Thapa, P. Marton (eds.), The Palgrave Encyclopedia of Global Security Studies, Palgrave Macmillan, Cham 2020, pp. 1-7, https://doi.org/10.1007/978-3-319-74336-3 480-1.

Dordrecht: Springer Netherlands. https://doi.org/10.1007/978-94-007-6167-4_629-1.

Kristiansen, P., Taji, A., \& Reganold, J. P. (Eds.). (2006). Organic agriculture: A global perspective. Collingwood: CSIRO Publishing.

Lairon, D. (2010). Nutritional quality and safety of organic food: A review. Agronomy for Sustainable Development, 30(1), 33-41.

Lund, V, \& Röcklinsberg, H. (2001). Outlining a conception of animal welfare for organic farming systems. Journal of Agricultural and Environmental Ethics, 14 (4), 391 -424.

Lynch, D. (2009). Environmental impacts of organic agriculture: A Canadian perspective. Canadian Journal of Plant Science, 89(4), 621-628.

Meemken, E.-M., \& Qaim, M. (2018). Can private food standards promote gender equality in the small farm sector? Journal of Rural Studies, 58,39-51.

Minten, B., Dereje, M., Engida, E., \& Tamru, S. (2018). Tracking the quality premium of certified coffee: Evidence from Ethiopia. World Development, 101,119132.

Muller-Lindenlauf, M. (2009). Organic agriculture and carbon sequestration: Possibilities and constraints for the consideration of organic agriculture within carbon accounting systems. Rome: Food and Agriculture Organization of the United Nations.

Niggli, U. (2010). Organic agriculture: A productive means of low-carbon and high biodiversity food production. In Trade and environment review: Promoting poles of clean growth to foster the transition to a more sustainable economy (pp. 112-118). Geneva: United Nations Conference on Trade and Development.

Niggli, U. (2015). Sustainability of organic food production: Challenges and innovations. Proceedings of the Nutrition Society, 74(1), 83-88.

Noe, E. (2006). The paradox of diffusion of organic farming: A case study in Denmark. In G. Holt \& M. Reed (Eds.), Sociological perspectives of organic agriculture: From pioneer to policy (pp. 210-226). Wallingford: CABI.

Rice, C. W., \& Owensby, C. E. (2001). The effects of fire and grazing on soil carbon in rangelands. In R. F. Follett, J. M. Kimble, \& R. Lal (Eds.), The potential of U.S. grazing lands to sequester carbon and mitigate the greenhouse effect (pp. 323-342). Boca Raton: Lewis Publishers.

Seufert, V., \& Ramankutty, N. (2017). Many shades of gray: The context-dependent performance of organic agriculture. Science Advances, 3(3), e1602638.

Treu, H., Nordborg, M., Cederberg, C., Heuer, T., Claupein, E., Hoffmann, H., \& Berndes, G. (2017). Carbon footprints and land use of conventional and organic diets in Germany. 
M. Klimczuk-Kochańska, A. Klimczuk, Organic Agriculture, [in:] S.N. Romaniuk, M. Thapa, P. Marton (eds.), The Palgrave Encyclopedia of Global Security Studies, Palgrave Macmillan, Cham 2020, pp. 1-7, https://doi.org/10.1007/978-3-319-74336-3 480-1.

Journal of Cleaner Production, 161, 127-142.

Truninger, M. (2008). The organic food market in Portugal: Contested meanings, competing conventions. International Journal of Agricultural Resources, Governance and Ecology, $7(1-2), 110-125$.

Verhoog, H., Matze, M., van Bueren, E. L., \& Baars, T. (2003). The role of the concept of the natural (naturalness) in organic farming. Journal of Agricultural and Environmental Ethics, 16(1), 29-49.

Visser, W. (2011). The age of responsibility: CSR 2.0 and the new DNA of business. London: Wiley.

Willer, H., Rohwedder, M., \& Wynen, E. (2009). Organic agriculture worldwide: Current statistics. In H. Willer \& L. Kilcher (Eds.), The world of organic agriculture: Statistics and emerging trends 2009 (pp. 25-58). Bonn: IFOAM. 